\title{
The best is yet to come: Repair of thoracoabdominal aortic aneurysms
}

\author{
Grayson H. Wheatley III, MD
}

\author{
From Siragusa Vascular, LLC, Nashville, Tenn. \\ Disclosures: Dr Wheatley serves as a consultant for Medtronic, Terumo Aortic, Endologix, and Ethicon. \\ Received for publication May 15, 2018; revisions received May 15, 2018; accepted for publication May 16, 2018; \\ available ahead of print June 27, 2018. \\ Address for reprints: Grayson H. Wheatley III, MD, 28 White Bridge Pike, Suite 200, Nashville, TN 37205 \\ (E-mail: ghw3rd@gmail.com). \\ J Thorac Cardiovasc Surg 2018;156:2051-2 \\ $0022-5223 / \$ 36.00$ \\ Copyright $(C) 2018$ by The American Association for Thoracic Surgery \\ https://doi.org/10.1016/j.jtcvs.2018.05.065
}

Contemporary procedural techniques for open surgical repair of thoracoabdominal aortic aneurysms (TAAAs) retain many of the fundamental principles espoused by E. Stanley Crawford more than 40 years ago. ${ }^{1}$ Outcome benchmarks in the modern era for open TAAA repair have been well established by high-volume centers. ${ }^{2,3}$ In this issue of the Journal, Mkalaluh and colleagues ${ }^{4}$ report their institutional experience with open TAAA repair during a 10-year period at a non-high volume center.

The group in Heidelberg has provided us with a potential window into the future of open TAAA repair at a time when many cardiovascular centers contemplate whether to continue their open TAAA repair programs or refer their patients out to high-volume aortic centers of excellence. They performed 38 open TAAA repairs during the 10-year study period (3.8 cases/year), with a $7.9 \%$ paraplegia rate and an overall mortality of $10.5 \%$ (4 patients). These results are within the range of accepted published outcomes reported by high-volume centers. ${ }^{3,4}$ Importantly, their surgical technique and methods for open TAAA repair are similar to those used by high-volume centers. Their outcomes with patients with connective tissue disorders also mirrored those of high-volume centers. Crawford extent II aneurysm anatomy was the predominant morphology treated in the study (57.9\% patients), with a 30-day mortality consistent with other published studies for extent II aneurysms, and this is notable because extent II aneurysms have been shown to have a higher associated mortality. ${ }^{1}$

In addition to validating open surgical repair as the criterion standard for TAAA repair in non-high volume centers, this study also helps us better gauge the comparative efficacies of open versus endovascular TAAA repair. Because most patients with TAAAs undergo initial triage at a non-high volume open TAAA repair centers, clinicians are often faced with the dilemma of whether to refer patients with TAAAs to a high-volume center to optimize open surgical outcomes or move forward with a less-invasive endovascular approach with branched or fenestrated technologies. At present, outcomes for endovascular TAAA repair are in evolution.

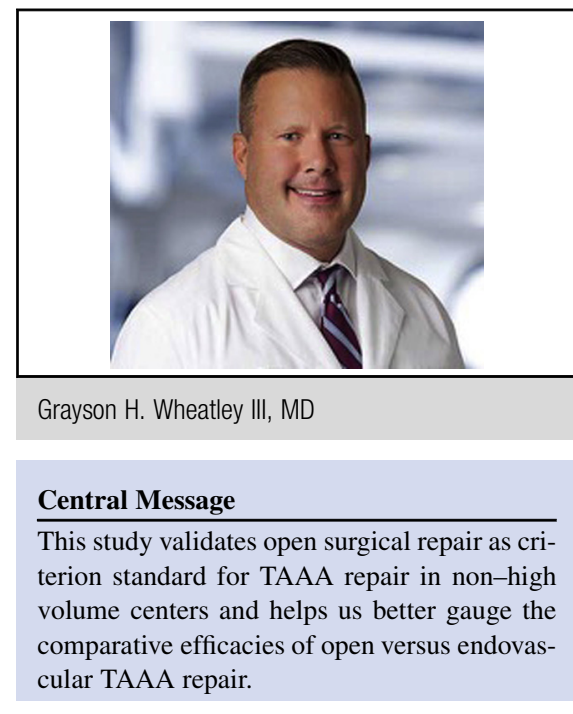

See Article page 2067.

There are a variety of different endovascular technologies available for TAAA repair, including branched, fenestrated, and inner-branched endografts. ${ }^{5-7}$ Outcomes associated with these early, first-generation endovascular technologies are slightly higher (10\% 30-day mortality) than with open TAAA repair, with a similar re-intervention rate and no significant survival advantage compared with open surgical repair beyond 24 months.

Decision making for the optimal treatment of patients with TAAA in a majority of medical centers is driven in part by the perception that mortality associated with open TAAA repair is generally higher at non-high volume centers. With this study, clinicians now have data to better compare "real-world" open TAAA repair outcomes with endovascular TAAA repair outcomes for the majority of medical centers that constitute non-high volume open surgical repair programs. It is likely that results for both open and endovascular TAAA repair will improve with time as new technologies and techniques become available. In both scenarios, it is clear that for the treatment of patients with TAAA, the best is yet to come.

\section{References}

1. Crawford ES. Thoraco-abdominal and abdominal aortic aneurysms involving renal, superior mesenteric, celiac arteries. Ann Surg. 1974;179:763-72.

2. Coselli JS, LeMaire SA, Preventza O, de la Cruz K, Cooley D, Price MD, et al Outcomes of 3309 thoracoabdominal aortic aneurysm repairs. J Thorac Cardiovasc Surg. 2016;151:1323-38. 
3. Aftab M, Songdechakraiwut T, Green SY, Zarda S, Price MD, Nalty CC, et al. Contemporary outcomes of open thoracoabdominal aortic aneurysm repair in octogenarians. J Thorac Cardiovasc Surg. 2015;149(2 Suppl): S134-41.

4. Mkalaluh S, Szczechowicz M, Dib B, Weymann A, Szabo G, Karck M Open surgical thoracoabdominal aortic aneurysm repair: the Heidelberg experience. J Thorac Cardiovasc Surg. 2018;156:2067-73.

5. Youssef M, Deglise S, Szopinski P, Jost-Phillipp S, Jomha A, Vahl CF, et al. A multicenter experience with a new fenestrated-branched device for endovascular repair of thoracoabdominal aortic aneurysms. J Endovasc Ther. 2018;25:209-19.

6. Katsargyris A, Marques de Marino P, Mufty H, Pedro LM, Fernandes R, Verhoeven EL. early experience with the use of inner branches in endovascular repair of complex abdominal and thoraco-abdominal aortic aneurysms. Eur J Vasc Endovasc Surg. 2018:55:640-6.

7. Hu Z, Li Y, Peng R, Liu J, Jia X, Liu X, et al. Multibranched stent-graft for the treatment of thoracoabdominal aortic aneurysms: a systematic review and meta-analysis. J Endovasc Ther. 2016;23:626-33.

Access to The Journal of Thoracic and Cardiovascular Surgery Online is reserved for print subscribers!

Full-text access to The Journal of Thoracic and Cardiovascular Surgery Online is available for all print subscribers. To activate your individual online subscription, please visit The Journal of Thoracic and Cardiovascular Surgery Online, point your browser to http://www.mosby.com/itcvs, follow the prompts to activate your online access, and follow the instructions. To activate your account, you will need your subscriber account number, which you can find on your mailing label (note: the number of digits in your subscriber account number varies from 6 to 10 ). See the example below in which the subscriber account number has been circled:

\section{Sample mailing label}

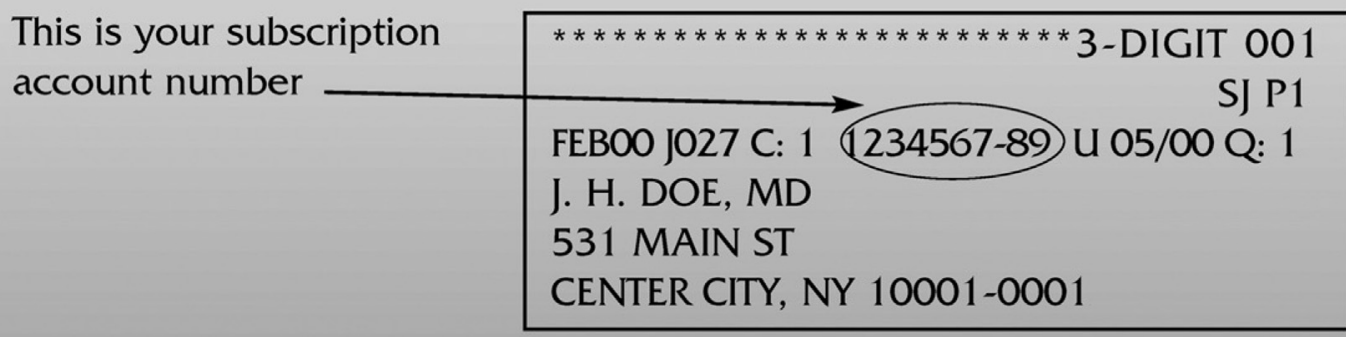

Personal subscriptions to The Journal of Thoracic and Cardiovascular Surgery Online are for individual use only and may not be transferred. Use of The Journal of Thoracic and Cardiovascular Surgery Online is subject to agreement to the terms and conditions as indicated online. 